\title{
FRAUD DEVELOPMENT AND LINKAGES WITH CORRUPTION OCCURRENCES
}

\author{
Afzal Izzaz Zahari1, ${ }^{*}$, Jamaliah Said ${ }^{1}$, and Roshayani Arshad1 \\ ${ }^{1}$ Accounting Research Institute, Universiti Teknologi MARA, Malaysia
}

ABSTRACT - This paper presents a review of the literature on connecting the relevance of fraud theory towards current and past cases that have already occurred globally. The local focus is towards the Malaysian public sector in terms of the harm that it has towards economic losses that are incurred when there are any actions of fraud. The discussion is through analysing different and varying definitions of fraud by various organisations and people. Discussion crosses throughout various perceptions of authors from different backgrounds such as accountancy, management, economics, psychology, financial crime and others. This paper first outlines the current fraud issues before relating these actions with fraud theories. These actions of fraud can be through collusion or allowed behaviours within each of the organisation. Although there are certain mechanisms in place such as internal control systems, these actions of fraud are still occurring in the current society. Findings indicate that fraud is a diverse and broad subject matter, it is always evolving and is an exciting field of research as more organisations or individuals will commit fraudulent actions although there are control mechanisms in place.
ARTICLE HISTORY

Received: 18-05-2019

Accepted: 03-07-2019

KEYWORDS

Corruption, Collusion, Fraud, Leadership, Prevention

\section{INTRODUCTION}

Fraud is an act of using dishonest methods in order to obtain something from someone else (ACFE, 2017). The concept of actions of fraud has always been associated with being corrupt or making fraudulent actions which cause indirect harm to their organisation. These actions of fraud behaviour directly cause financial and economic losses and have a long term impact towards their organisation (Adawiah, 1998; Ho, Li, Tam, \& Zhang, 2014). The organisations that are unable to handle the impact of fraud will either face foreclosure such as Enron, Arthur Anderson and WorldCom (Lunenburg, 2012; Rashid, Sambasivan, \& Rahman, 2004) are some of the international examples of organisations affected by actions of fraud. The paper also focuses on the Malaysian local perspective on how these fraud occurrences impact each of the organisations. The common ground is that each of these fraud cases had provided economic losses to the government financially or non-financially in terms of loss of reputations (Gee, Button, \& Brooks, 2011). The paper shows that although there are common control mechanism in the organisations such as audit reports and internal control mechanisms these actions of fraud are still a common occurrence. Such control mechanisms are thought to provide assurances towards the organisations in some cases of these fraud actions were the leaders themselves are the ones involved and instructing the organisations to commit those actions (Free \& Macintosh, 2006). The paper expresses the small scale fraud that occurs in various government bodies to high levels of fraud cases that have occurred throughout the years. These are the common overlay of the definitions of fraud as provided by various bodies from accounting, financial and professional organisations. Table 1 presents an overall outlay of what defines fraud from different approach and outlooks.

Table 1: Range of fraud definitions

Source

AICPA, 2006

ACFE, 2016

Keller \& Owens, 2015

CIMA, 2008

XVI INCOSAI

\section{Definition of fraud}

Wilful misrepresentations made with an intention to deceive others.

Use of one's occupation for personal enrichment through the deliberate misuse or misapplication of employing organization's resources or assets.

Internal and external fraud. Internal frauds are committed by individuals in the entity. External frauds are committed by individuals outside the entity.

Activities such as theft, corruption, conspiracy, embezzlement, money laundering, bribery and extortion

Unlawful interaction between two entities, where one party intentionally deceives the other by means of false representation in order to gain an illicit and unjust advantage. It involves acts of deceit, trickery, concealment, or breach of confidence that are used to gain an unfair or dishonest advantage.

Source: (ACFE, 2016; AICPA, 2006; CIMA, 2008; INTOSAI, 2016; Owens, 2015) 
Fraud through misappropriation of assets is the most common method found throughout most organisations (ACFE, 2016). This is supported by research by Price Waterhouse Coopers, where the most common occurrence of fraud can be found in a form of asset mismanagement (Price Waterhouse Coopers, 2016). This method occurs when individuals who hold the trust as caretakers of organisational assets use it for their own benefits.

Asset mismanagement can lead to economic losses, where these assets could have otherwise been put to better use in helping national growth. Realising its consequence towards a global economy, academic research on fraud is vital for practitioners to have more knowledge on to counter fraud strategies that can be further developed in improving organisational efficiency (Button \& Brooks, 2009). This asset mismanagement can be interpreted as actions of fraud where people abuse their power in committing these offences (Wilson et al., 2014)

There are three anti-fraud programmes which are commonly discussed in fraud literature. They include fraud deterrence, fraud prevention and fraud detection (Petrucelli \& Peters, 2016). Fraud deterrence is done by having barriers which are designed to persuade any individual not to commit actions of fraud. Threats of being caught by authorities through these barriers are an example of this method. Fraud prevention is a strategy to prevent individuals from committing actions of fraud. The use of an internal control mechanism is an example of fraud prevention techniques. For example, through levers of control, approval from two senior government officials is needed to approve any contract payment. Lastly, fraud detection is a method of using investigative techniques to discover any allegations by external parties when the other two programmes are deemed to be less effective in their use

\section{LITERATURE REVIEW}

\section{Current Issues}

KPMG's Fraud, Bribery and Corruption Survey (KPMG, 2013) recently found that 83 per cent of men is likely perceived to be a typical fraudster as compared to 17 per cent of women, based on the survey's respondents. Their results showed that male fraudster is likely to be aged between 26 to 40 years old, earning an annual income of RM60,000 and below, and has been with an organisation for less than 5 years. A situation such as these can occur on an assumption that specific departments have a weak internal control system. When there is collusion towards these actions of fraud, the losses will increase incrementally according to the number of people doing these actions of fraud, meaning that the losses will be higher with the increased amount of people involved (Wilson et al., 2014). The following table describes a brief summary of the previous graft and corruption cases that had occurred in Malaysia.

Table 2: Summary of corruption cases that had occurred in Malaysia $(2015-2018)$

\begin{tabular}{|c|c|c|c|c|c|}
\hline Year & Fraud loss (RM) & Type of fraud & Department & $\begin{array}{c}\text { Accused } \\
\text { perpetrator }\end{array}$ & Source \\
\hline 2018 & $4,000,000.00$ & Bribery & $\begin{array}{l}\text { Perlis Water } \\
\text { Department }\end{array}$ & Director & $\begin{array}{c}\text { Jamaludin, } \\
2018\end{array}$ \\
\hline 2018 & $2,700,000.00$ & Corruption charge & $\begin{array}{l}\text { Sabah Railway } \\
\text { Department }\end{array}$ & Deputy Director & Miwil, 2018 \\
\hline 2017 & $789,360.00$ & False claims & $\begin{array}{l}\text { Petronas } \\
\text { (Government Linked } \\
\text { Company) }\end{array}$ & $\begin{array}{l}\text { Coordinator } \\
\text { Officer }\end{array}$ & MACC, 2017 \\
\hline 2017 & $420,852.00$ & $\begin{array}{c}\text { Tender Supply of } \\
\text { Goods }\end{array}$ & $\begin{array}{l}\text { Royal Malaysian } \\
\text { Navy }\end{array}$ & $\begin{array}{c}\text { Officers of the } \\
\text { Royal Malaysian } \\
\text { Navy }\end{array}$ & MACC, 2017 \\
\hline 2017 & $2,500,000.00$ & Graft & $\begin{array}{l}\text { TH Heavy } \\
\text { Engineering } \\
\text { (Government Linked } \\
\text { Company) }\end{array}$ & $\begin{array}{l}\text { Chief Executive } \\
\text { Officer (CEO) }\end{array}$ & MACC, 2017 \\
\hline 2017 & $150,000.00$ & Issuance of permit & $\begin{array}{l}\text { Johor Bahru } \\
\text { Municipal Council }\end{array}$ & $\begin{array}{c}\text { Assistant } \\
\text { Administrative } \\
\text { Officer (PTD) }\end{array}$ & MACC, 2017 \\
\hline 2017 & $40,000.00$ & Graft & $\begin{array}{l}\text { State Office Kuantan, } \\
\text { Malaysia }\end{array}$ & Civil Servant & $\begin{array}{c}\text { Sinar Harian, } \\
2017\end{array}$ \\
\hline 2016 & $38,000,000.00$ & $\begin{array}{l}\text { Misappropriating } \\
\text { Government Funds }\end{array}$ & $\begin{array}{l}\text { Ministry of Sports } \\
\text { Malaysia }\end{array}$ & $\begin{array}{c}\text { Finance Division } \\
\text { Secretary }\end{array}$ & $\begin{array}{c}\text { Gunaratnam, } \\
2016\end{array}$ \\
\hline
\end{tabular}




\section{Year Fraud loss (RM) Type of fraud Department $\quad \begin{gathered}\text { Accused } \\ \text { perpetrator }\end{gathered}$ Source}

\begin{tabular}{|c|c|c|c|c|c|}
\hline 2016 & $114,500,000.00$ & Abuse of Power & $\begin{array}{l}\text { Sabah State Water } \\
\text { Department }\end{array}$ & $\begin{array}{l}\text { Director and } \\
\text { Deputy Director } \\
\text { of Utilities } \\
\text { Department }\end{array}$ & Chan, 2016 \\
\hline \multirow{3}{*}{2016} & $930,000.00$ & Graft through assets & $\begin{array}{l}\text { Kuala Lumpur } \\
\text { Municipal Council }\end{array}$ & $\begin{array}{l}\text { Executive } \\
\text { Director }\end{array}$ & \\
\hline & $1,900,000.00$ & Graft through assets & & $\begin{array}{l}\text { Deputy Director } \\
\text { of Finance }\end{array}$ & $\begin{array}{l}\text { BERNAMA, } \\
2016\end{array}$ \\
\hline & $1,650,000.00$ & Illegal Activities & & & \\
\hline 2016 & $45,572.30$ & $\begin{array}{l}\text { Graft through } \\
\text { tenders }\end{array}$ & $\begin{array}{l}\text { Malacca Stadium } \\
\text { Body }\end{array}$ & $\begin{array}{l}\text { Assistant Director } \\
\text { (Finance and } \\
\text { Management) }\end{array}$ & $\begin{array}{l}\text { BERNAMA, } \\
2016\end{array}$ \\
\hline 2015 & $13,700,000.00$ & $\begin{array}{l}\text { Over purchase of } \\
\text { Assets }\end{array}$ & $\begin{array}{l}\text { Majlis Amanah } \\
\text { Rakyat Malaysia } \\
\text { (Mara Incorporated) }\end{array}$ & Company Director & $\begin{array}{l}\text { BERNAMA, } \\
2015\end{array}$ \\
\hline 2015 & $49,700,000.00$ & $\begin{array}{c}\text { Criminal Breach of } \\
\text { Trust }\end{array}$ & $\begin{array}{l}\text { National Feedlot } \\
\text { Corporation (NFC) }\end{array}$ & $\begin{array}{c}\text { Chief Executive } \\
\text { Officer }\end{array}$ & $\begin{array}{l}\text { BERNAMA, } \\
2015\end{array}$ \\
\hline 2015 & $3,000,000.00$ & Graft through assets & Selangor Ministry & $\begin{array}{c}\text { Former Chief } \\
\text { Minister of } \\
\text { Selangor }\end{array}$ & Nazlina, 2015 \\
\hline
\end{tabular}

Source: (BERNAMA, 2015, 2016b, 2016a; Chan, 2016; Gunaratnam, 2016; Jamaludin, 2018; MACC, 2017a, 2017b, 2017c; Miwil, 2018; Nazlina, 2015; Sinar Harian, 2017)

Based on the previous table, there have been a number of cases involving fraud and corruption that had occurred in Malaysia throughout the year 2015 to 2018. The case in 2018 involved the Perlis Water Department where the director was charged with abuse of power and corruption of receiving bribes of up to RM 4,000,000 (Jamaludin, 2018). The Sabah Railway Department deputy director has corruption charges amounting to RM 2,700,000 of where four members of the staff were also included in the indictment (Miwil, 2018)

The involvement of Petronas, which is a government-linked company (GLC), the officer was making false claims totalling up to an amount of RM789,369 with another private supply company (MACC, 2017c). The following case involves the Royal Malaysian Navy (RMN). The husband and wife were both working at RMN during the incident, where they approved projects that were worth RM1,363 million. With that approval, they received kickbacks totalling an amount of RM420,852 (MACC, 2017b). A CEO of another government-linked company (GLC), namely TH Heavy Engineering, was found to be involved with breach of trust in issuing five cheques worth RM400,000, RM570,000, RM430,000, RM600,000 and RM575,800 on separate dates (MACC, 2017a), these cheques had been abused for personal use which leads to the actions of fraud. In a separate case, a Johor Bahru Municipal Council administrative officer was involved in graft through the issuance of permits for a private company, for which the administrative officer had received monetary incentives worth RM150,000 (MACC, 2017d). Additionally, two civil servants in Kelantan State Office received graft money up to RM 40,000 (Sinar Harian, 2017)

Throughout 2016, there have also been some noticeable cases involving fraud within the Malaysian government. Cases of the Youth and Sports Ministry had been involved with misappropriation of funds amounting to RM38,000,000 (Gunaratnam, 2016). Towards the end 2016, a case of Sabah State Water Department had linked high ranking officials of government servants to corruption, where their seized assets had totalled up to an amount of RM114,500,000 (Chan, 2016). Kuala Lumpur Municipal Council also had a few cases involving fraud during that year. They involved the local government's executive director and deputy director of finance. The amount of fraud loss had totalled RM4,480 million ringgit (Firdaous Fadzil, 2016). Further, an assistant director of Malacca Stadium Body, who controls the body's finance and management matters, was also found to had been involved with graft with an amount of RM45,572.30. The assistant director had previously approved contracts for projects awarded to her brothers' company (BERNAMA, 2016b). 
The year 2015 had also seen some high profile cases in Malaysia. A case of Majlis Amanah Rakyat's (MARA) incorporated company holding assets in Australia was the limelight of 2015. This company bought assets in Australia which were overpriced to be above the actual market value. Kickbacks were then transferred to interested parties who had dealings prior to the assets' purchases. It was then later discovered that the amount of 4.75 million Australian dollars were laundered out of Australia (Nick McKenzie, Richard Baker, 2015). The case of National Feedlot Corporation (NFC) in 2015 had also sparked some concerns regarding the misuse in government facilities, particularly regarding soft loans that were provided to the corporation. The CEO of NFC was accused to have breached the trust of government loan facilities amounting RM 49.7 million. He was however released not long after that, as accusations were dropped by the high court of Malaysia (BERNAMA, 2015). Separately, a former Chief Minister of Selangor was found guilty of the graft through receipt of kickbacks in assets. This case was developed when it was discovered that the Chief Minister had purchased a house that is below the market price, with its difference amounting RM 3 million (Nazlina, 2015).

Globally, actions of fraud had caused the world trillions of under-recorded losses. Occupational fraud had caused a total loss of more than 9.76 trillion dollars within the year 2015 alone (ACFE, 2016). Average fraud loss is found to be around 703,000 dollars for an owner or executive; 173,000 dollars for a manager; and 65,000 dollars for employees that commit fraud. The more collusion occurs in an occupational fraud, the higher losses are recorded individually. Loss of 65,000 dollars is discovered from a person, 150,000 dollars from two persons, 220,000 dollars from three persons, 294,000 dollars from four persons and an average loss of 633,000 dollars is found from five persons or more (ACFE, 2016). The United Kingdom economy, for example, suffered an estimated loss up to 193 billion pounds a year due to fraud (Button, 2016). These losses are very significant to organisations such as governments, as they are the biggest cluster of organisations in the world. Corporations or companies could not compare to the effects that a government has in terms of policy and spending. These fraud losses are hence significant and can be avoided through fraud prevention, in which internal control, organisational culture, QMS and integrity play a role in preventing leakages.

Past records of organisational fraud in governments are limited in terms of substantial numbers. However, there are some examples of organisational occurrences of fraud that can be collected internationally, and it has had quite a history over the century. The table below displays an extent of organisational fraud that had occurred globally over the years (Table 3).

Table 3: Summary of international fraud occurrences

\begin{tabular}{|c|c|c|c|c|c|c|}
\hline Year & $\begin{array}{c}\text { Fraud } \\
\text { Loss }\end{array}$ & Organisation & Type of Fraud & $\begin{array}{c}\text { Level of } \\
\text { fraud }\end{array}$ & $\begin{array}{c}\text { Accused } \\
\text { Perpetrator }\end{array}$ & Source \\
\hline 1995 & $\begin{array}{l}825 \\
\text { million } \\
\text { pounds }\end{array}$ & Baring Bank & $\begin{array}{l}\text { Investment } \\
\text { fraud }\end{array}$ & $\begin{array}{c}\text { Senior } \\
\text { management }\end{array}$ & Nick Leeson & $\begin{array}{l}\text { Rodrigues, } \\
2015\end{array}$ \\
\hline $\begin{array}{l}1996 \\
\text { to } \\
2003\end{array}$ & $\begin{array}{l}2.7 \text { billion } \\
\text { dollars }\end{array}$ & $\begin{array}{l}\text { Healthcare } \\
\text { Incorporated }\end{array}$ & $\begin{array}{l}\text { Accounting } \\
\text { fraud }\end{array}$ & CEO & Richard Scrushy & $\begin{array}{l}\text { Lupica, } \\
2014\end{array}$ \\
\hline 2001 & $\begin{array}{l}50 \text { billion } \\
\text { dollars }\end{array}$ & Enron & $\begin{array}{c}\text { Falsified } \\
\text { earnings } \\
\text { False statements } \\
\text { Insider trading }\end{array}$ & $\begin{array}{c}\text { CEO \& } \\
\text { founder } \\
\text { Company's } \\
\text { auditor }\end{array}$ & $\begin{array}{l}\text { Jeffrey Skilling } \\
\text { \& Kenneth Lay } \\
\text { Arthur Anderson }\end{array}$ & $\begin{array}{c}\text { Richard Jr. } \\
\text { \& A. R. } \\
\text { Sorking, } \\
2001\end{array}$ \\
\hline 2001 & Dissolution & Arthur Anderson & False statements & Partner & $\begin{array}{l}\text { Michael M. } \\
\text { Lowther }\end{array}$ & $\begin{array}{c}\text { Dugan, } \\
2002\end{array}$ \\
\hline 2001 & $\begin{array}{l}13 \text { billion } \\
\text { dollars }\end{array}$ & Swiss Air & Mismanagement & $\begin{array}{c}\text { CFO } \\
\text { Officers, } \\
\text { directors } \\
\text { and advisors }\end{array}$ & Jacqualyn Fouse & $\begin{array}{l}\text { Stephen } \\
\text { Taub, } \\
2006\end{array}$ \\
\hline 2001 & $\begin{array}{l}4 \text { billion } \\
\text { euros }\end{array}$ & Parmalat & $\begin{array}{c}\text { Financial fraud } \\
\text { and money } \\
\text { laundering }\end{array}$ & CEO & Calisto Tanzi, & $\begin{array}{c}\text { World } \\
\text { Finance, } \\
2011\end{array}$ \\
\hline 2002 & $\begin{array}{l}600 \\
\text { million } \\
\text { dollars }\end{array}$ & Tyco & $\begin{array}{c}\text { Falsified } \\
\text { expense account }\end{array}$ & $\begin{array}{l}\text { CEO } \\
\text { Financial } \\
\text { advisor }\end{array}$ & $\begin{array}{c}\text { Dennis } \\
\text { Kozlowski Mark } \\
\text { H. Swartz }\end{array}$ & $\begin{array}{l}\text { A. R. } \\
\text { Sorking, } \\
2002\end{array}$ \\
\hline 2002 & $\begin{array}{l}2.2 \text { billion } \\
\text { dollars }\end{array}$ & $\begin{array}{c}\text { Adelphia } \\
\text { Communications }\end{array}$ & $\begin{array}{c}\text { Off-balance } \\
\text { sheet }\end{array}$ & Founders & $\begin{array}{c}\text { John Rigas } \\
\text { Timothy Rigas }\end{array}$ & $\begin{array}{l}\text { J. Maron } \\
\& \\
\text { R.Frank, } \\
2002\end{array}$ \\
\hline 2003 & $\begin{array}{l}2.3 \text { billion } \\
\text { dollars }\end{array}$ & Banco & Bank fraud & $\begin{array}{l}\text { CEO Vice } \\
\text { president }\end{array}$ & $\begin{array}{c}\text { Ramón Báez } \\
\text { „Figueroa } \\
\text { Marcos Báez } \\
\text { Cocco } \\
\text { Vivian Lubrano } \\
\text { de Castillo } \\
\end{array}$ & $\begin{array}{l}\text { The } \\
\text { Economist, } \\
2003\end{array}$ \\
\hline
\end{tabular}




\begin{tabular}{|c|c|c|c|c|c|c|}
\hline Year & $\begin{array}{c}\text { Fraud } \\
\text { Loss }\end{array}$ & Organisation & Type of Fraud & $\begin{array}{c}\text { Level of } \\
\text { fraud }\end{array}$ & $\begin{array}{c}\text { Accused } \\
\text { Perpetrator }\end{array}$ & Source \\
\hline & & & & & $\begin{array}{c}\text { Jesús M. } \\
\text { Troncoso } \\
\text { Luis Alvarez } \\
\text { Renta }\end{array}$ & \\
\hline
\end{tabular}

Source: (Dugan, 2002; Frank, 2002; Junior \& Sorking, 2001; Lupica, 2014; Rodrigues, 2015; Sorking, 2002; Taub, 2006; The-Economist, 2003; World-Finance, 2011)

Baring Bank is a British merchant bank, with a history dated back in 1762. This bank failed in 1995 due to poor speculative investment in future contracts, suffering losses of 830 million pounds (Rodrigues, 2015). Failure of this bank was mainly due to weak internal controls, as the perpetrator, Nick Leeson was in control of two critical positions in the bank, which were as floor manager of trading and the head of settlement operations. These weaknesses in control had led the perpetrator to exploit the system with weak risk management practices. Meanwhile, Healthcare Incorporated is a medical related industry organisation that was involved with an accounting scandal with over inflating earnings amounting 1.4 billion dollars. This scandal had led the company to lose a total amount of 2.7 billion dollars (Lupica, 2014). Facts of this scandal stated that the company's CEO Richard M. Scrushy had instructed his senior accountants to overstate company profit by 4700 per cent. In another case, Tyco Limited was involved in a scandal which saw the company losing 600 million dollars (Sorking, 2002). Tyco Limited's CEO and financial advisor were involved in racketeering funds up to 600 million dollars. They made unauthorised bonuses, falsified expense accounts and stock fraud during that time. This case occurred from a leadership perspective of committing fraud by having low levels of integrity within the organisation.

Fast forward a few years, Enron emerged to become the pinnacle of fraud in organisations. The company's fraudulent behaviour had led to the introduction of the Sarbanes Oxley Act (2002). When the fraud case happened, Enron suffered losses of up to 50 billion dollars (Free, Macintosh, \& Stein, 2007; Junior \& Sorking, 2001; Olagbemi, 2010). Various case studies had reflected on this organisation, particularly with concerns of organisational behaviour and control. Enron's CEO Jeffrey Skilling and founder Kenneth Lay perpetrated the fraud by hiding the company's losses, subsequently being found guilty of conspiracy and fraud. Their auditor Arthur Anderson was also found guilty for illegally destroying documents that are relevant to the fraud investigation, which had led to the dissolution of one of the biggest audit firm in the United States (Dugan, 2002; Edelman \& Nicholson, 2005). Michael M. Lowther was the partner in charge of Arthur Andersen's energy audit division. Being indirectly involved in the fraud case, he ignored the risks involved with Enron financial transactions; hence he was charged for violation of legal practices.

Further, Swissair suffered losses amounting 13 billion dollars, which had made the company become insolvent. Swissair CFO was subsequently faced with charges of mismanagement, the unfaithful business conducts and favouring creditors (Taub, 2006). The company's eighteen former employees, officers and directors were also charged by the Swiss court with various fraud offences. In Italy, it's international dairy company Parmalat fell short when the bondholders discovered that 4 billion Euros were of non-existent funds. The auditors had also discovered a gap of 14.3 billion Euro in their finance. Parmalat's CEO Calisto Tanzi was then found to be guilty of financial fraud and money laundering (WorldFinance, 2011). In the Dominican Republic, the lavish lifestyle of Banco's CEO Báez Figueroa was discovered to be due to mismanagement of the second largest commercial bank in the republic. Figueroa, along with vice presidents of the bank was charged with bank fraud and money laundering amounting 2.3 billion dollars (The-Economist, 2003). Finally, Adelphia Communication Corporation, which was the sixth largest cable-television company based in Pennsylvania, was declared to be bankrupt in 2002 due to a discovery of 2.3 billion dollars off its balance sheet debts. Three family members were charged with financial fraud by using sophisticated cash-management systems to divert the money to family-owned entities (Frank, 2002).

The summary of these organisational fraud occurrences indicates that when there are losses in the organisation, the level of fraud loss will be very material in terms of number. Actions of organisational fraud would usually require more than one individual or group, which colludes to disengage their control environment in order to commit these crimes

\section{PROBLEM STATEMENT}

The issue here is that this occurrence of fraud still occurs although there are control mechanisms in these organisations. The losses or economic losses that occur due to fraud and corruption incur more financial costs (Gee et al., 2011). From the year 2014 to 2016, the rate of corruption in the government sector had decreased as reported by Malaysian Anticorruption Agency (MACC). 38.8\% of corruption offenders in 2016 are government employees (MACC, 2016). The losses due to fraud are 65,000 dollars from a person, 150,000 dollars two persons, 220,000 dollars three persons, 294,000 dollars four persons and an average of 633,000 dollars from five persons or more.

It can be seen that fraud and corruption will lead to losses to any organisation and government. These entities are always searching for methods to prevent and control fraud in their organisation. Identifying the proper approach is important in order to prevent corruption. The rate of fraud becomes higher when more people are involved in acts of corruption or when there is collusion.

This paper provides an analysis towards understanding why these cases are still happening whether in large multinational organisations or public sector organisations. The search for appropriate tools is critical in order for these 
organisations to control the losses that could have been put for better use. Such tools could include improving the controls of internal control systems in the organisation, ethical leadership styles, enforcing stronger and stricter actions over fraudsters.

The overall cases presented in this paper shows that organisational weaknesses are amongst the contributing factors towards fraud and corruption. These actions had also shown the importance of leadership in organisations that directly allowed and executed such acts of corruption. The review provides a conception that fraud will still occur in this modern day and age of technologies. The methods of preventing and discouraging these acts should be further studies in future studies.

\section{THEORETICAL DISCUSSION}

Fraud triangle theory is a theoretical model of approach which explains the reasoning behind any individual who commits fraud (ACFE, 2017; Cressey, 1953, 1973). The initial observation was made from Cressey's psychologist point of view, in terms of why humans tend to commit fraud. This research suggested that there are three components behind the reasoning, which are perceived as an unshakeable financial need, perceived opportunity and rationalisation. Perceived unshakeable financial need in situations where the individual is pressured to make such fraudulent actions due to financial constraints.

The initial development of the fraud triangle theory was done by Cressey using three components. These components, as previously mentioned, act as the enabler of fraud. By having one of these components in an individual, the person can, and will, commit fraud. Fraud diamond adds an additional component to the triangle, which is the capability of an individual to commit an act of fraud (Wolfe \& Hermanson, 2004). Other expansions towards the fraud triangle include additions of competence and arrogance components (Horwarth, 2014), which was developed by an accounting organisation. The component of competence is an approach of individuals' ability to override internal controls and control the situation according to the person who will be committing the fraud. Arrogance is a lack of consciousness, where an individual feels that they are entitled to receive resources, while policies and procedures of the organisation are not applicable to them. These are some brief examples and explanations concerning the fraud theory.

Fraud scale theory was developed by Albrecht, Howe and Romney in 1984 (W. Steve, Ketich R., \& Marshall B., 1984). These researchers provided an alternate approach towards the fraud triangle. Fraud scale is similar to the fraud triangle, where instead of rationalisation; the fraud scale uses personal integrity within its model. This is because personal integrity can be observed in through individual or organisation settings of measurements as compared to rationalisation (Ruankaew, 2013). Assessment of integrity can be observed and measured in terms of possibilities that an individual will commit an act of fraud in his or her organisation. Prior literature stated that occurrence of fraud and unethical behaviours are due to the lack of integrity or other moral ethics that affect an individual's decision making (Jack, Arron Scott, \& Mary-Jo, 2010). The attitude that morally acceptable rationalisation occurs before an act of fraud makes fraudsters to often view that while their actions as unethical, these actions are justified as they view their actions to be morally acceptable (Ruankaew, 2016).

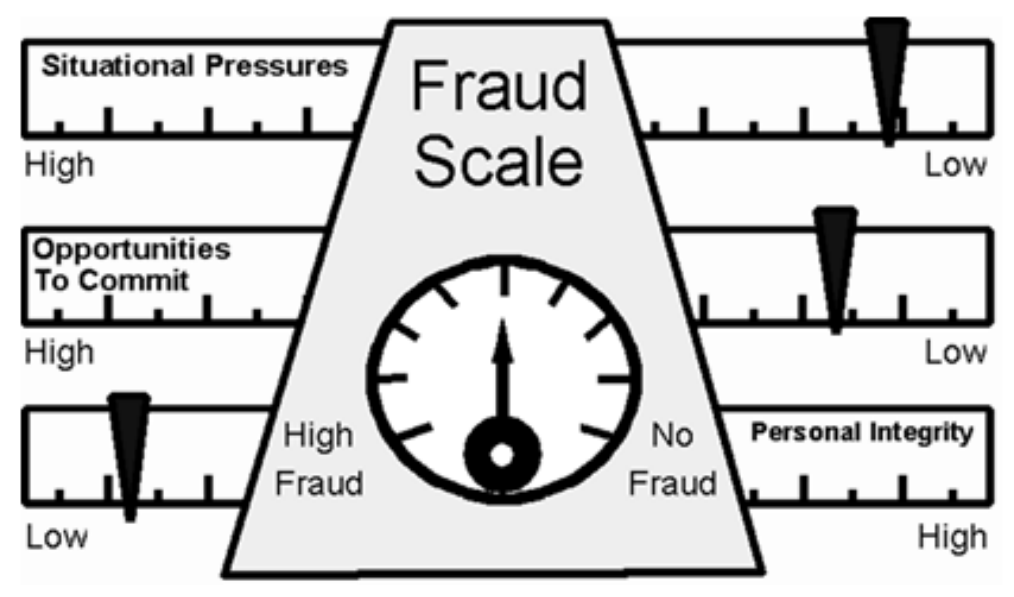

Source: (Steve et al., 1984)

Figure 1: The Fraud Scale Theory

Figure 1 is a graphical presentation of when a scale, for example, personal integrity scales down towards the lower side; there will be a higher probability that the individual will commit fraud. The same principle is applied towards pressure and opportunities, which are the components of fraud scale theory. Related literature indicated that there are nine motivators of fraud. These motivators include when the individual is living beyond their means, with overwhelming desire for personal gain, high amount of personal debt, close association with customers, pay of work does not commensurate 
with the work being done, a wheeler-dealer attitude, desire to challenge the system, excessive gambling debts, and pressure from friends and family.

A study by Hollinger-Clark investigated real-time survey on 10,000 employees concerning fraud (Hollinger \& Clark, 1983). Their findings showed that personal income and fraud has little correlation to one another; there is a positive correlation between job dissatisfaction and fraud, and there is a negative correlation between control and employee deviance (acts against property or violations). In this study, they observed five aspects of company policies, selection of personnel, inventory control, security and punishment. Employees' perception towards control is important in order to deter fraud, hence management should be more concerned and sensitive towards their employees.

The notion of fraud triangle suggested that the three factors of pressure, opportunity and rationalisation must be in place in order for an act of fraud to occur. Walmart's former vice-chairman was involved in allegations of fraud, where he had his employees to create fake invoices and documents for Walmart to pay, while in actual fact those were his personal expenses (Bandler \& Zimmerman, 2005). The component of financial pressure from Cressey's model does not match with the former vice-chairman's case, as he received annual compensations of 6 million dollars. First Security Trust \& Savings Bank loan officer Jeffrey Gonsiewski altered loan payment periods of customers, causing the bank to lose 5.5 million dollars. Jeffery's motive was questionable, as he allegedly did not take any of the money. Changes were said to have been made in order to help struggling borrowers (Milwaukee, 2010). This fraud occurred in a form of changing due dates to an alternate period of time, changing monthly payments to become quarterly payments and principal interest payments to only include interest-only payments. These actions showed that first, the integrity of the said individual is in question and second, control aspects of the organisation were loose when it comes to people who are in charge of certain controls.

\section{Corruption: Asset Misappropriation}

Other than observation by ACFE and Price Waterhouse Coopers in 2016, asset misappropriation was also found to have the highest percentage economic crime of fraud committed by offenders in a 2015 Global Economic Survey. In addition to that, the New South Wales Auditors Generals survey had stated that the common type of fraud committed is theft of consumables cash and intangible assets, as well as procurement fraud such as false invoicing and fraudulent expenditure claims. The Australian National Audit Office (ANAO) addressed fraud activities such as the use of unauthorised operation of information technology, unauthorised access of information, forgery of records and fraud concerning ways the government conduct businesses as key points of methods that are used to commit fraud. Through fraud triangle, this survey indicated that the highest percentage of fraud committed by wrongdoers is due to incentive or pressure at 71 per cent, an opportunity at 15 per cent and attitude or rationalisation at 12 per cent. Some of the factors on why people commit fraud is also interesting, where fear of losing jobs is at 41 per cent, target or achievement of a department becoming difficult to be achieved at 37 per cent, senior management achieving desired results or target at 16 per cent and bonuses not being paid for that particular year at 11 per cent. Fear of losing jobs is due to government employees fearing that their department would come under scrutiny in cutting costs of non-essential services. This survey was helpful in identifying why government employees commit fraud, identifying indicators of the commonly used method, as well as identifying the reasons why people are inclined to commit fraud. The global survey suggested government sector to provide adequate fraud risk assessment programme, update risk assessments regularly, implement comprehensive fraud plan upon identifying new risk, uses data analysis to improve fraud detection, ensure that people who manage payment and procurement receive fraud detection training, and higher positioned people take action and initiatives in combating fraud. These are all some of the recommendations that were provided by the report in order to combat fraud in the government sector.

Moving towards the Malaysian context, PWC conducted a survey (Price Waterhouse Coopers, 2014) towards 38 listed companies concerning fraud development in Malaysia. Their findings showed that 42 per cent of respondents had experienced economic crime over the past two years. These findings support a major issue in Malaysia as almost half of the employees in the corporate sector are experiencing fraud or corruption incidences. Through this survey, asset misappropriation together with bribery and corruption becomes the top two types of economic crime being frequently reported in the survey. This survey also mentioned that having a whistleblowing hotline is the most effective way in combating fraud. The interesting element found in this survey was that researchers were able to profile Malaysian fraudsters based on respondents' feedback. Over the two periods of 2011 and 2014, most respondents believed that external parties are the one responsible for fraud cases. Internal parties that are responsible for fraud was expressed to have the following characteristics such as being male (75\%), a part of the middle management (67\%), aged up to 31 to 40 years old $(75 \%)$, at least being in service of 5 years in the organisation $(67 \%)$, and lastly the person holds a graduate degree $(83 \%)$. The important thing that was highlighted here is that a person with proper education and working experience are expressed by most respondents to be potentially involved with fraud, bribery and corruption. Part of this survey mentioned that pressure of financial performance may lead individuals to commit economic crimes. Also worth mentioning are impacts of this economic crime towards employees' morale, the affected organisations' product or brand, business relationship with partners or suppliers, relationship with regulators and share prices. These are all the impacts that were mentioned in their survey upon the activity of economic crime.

The Malaysian government has an annual auditor general's report, which is an audit that is carried out on all government ministries, statutory bodies, and government-linked assets. Auditor general's report is produced in terms of compliance and adherence of these assets towards laws and regulations, circumstances or parts of the government that can lead to inefficiency, as well as giving opinions toward prepared financial statements to be in accordance to financial 
and accounting standards. The report is subjected to the Malaysian Federal constitution act 1957, where the auditor general is required to submit his reports to the Malaysian King before the reports are tabled in Malaysia's House of Representatives. Audit Act 1957 empowers auditors to conduct a financial audit on these ministries and government bodies, as well as including other matters related to the deliverance of auditor general's report. The scope of auditorgeneral is placed towards performing audits on financial performance, physical performance, project performance, and service performance of the government. This is done by performing audits towards ministries, also performance audit and attestation audits. The explanation of the purpose for auditor general's report is on the linkage that it has towards fraud. The importance of their findings of inefficiency and misappropriation within government assets helps in terms of identifying possible fraud occurring in the government sector. As such, auditor-general's report indirectly becomes a tool towards fraud identification. Fraud prevention can be made through compliance audits, to identify whether or not government standard procedures are being properly adhered. The following are some examples from the auditor general's report that is related to fraud activities occurring in the Malaysian public sector. The auditor general's report in 2010 had identified some weaknesses in terms of Malaysian government efforts in identifying fraud cases. For instance, in a case of fund misappropriation, the marine parks department purchased marine binoculars for RM56,350, which is 2805 per cent higher than then normal market price of RM1,940; the LCD television and DVD players for RM16,100 which is 638 per cent higher than the market price of RM 2,182; as well as laptops and printers for RM11,845, which is 246 per cent higher than the market price of RM3428 (TheBorneoPost, 2011). In addition to that, the state agency Majlis Amanah Rakyat (MARA) had purchased an oven for RM1,200 with a market price of RM419; folding beds for RM500 with a market price of RM100; blenders at RM140 of which the market price is RM 60; as well as other examples of purchasing above the normal market price. This is indeed fraud occurring within the government sector, where officials were engaging with procurement frauds. Abuse of position or power towards procurement and opportunities arising within procedures are somewhat factors that lead to these economic crimes. It can, therefore, be summarised that the current perspective on most Malaysian organisations fails to carry out proper enforcement of their internal control systems, which would influence the effectiveness of organisations in maintaining control. The mentioned cases involving abuse of control system within government organisations are potential indicators that Malaysia might have a weak internal control system, a control environment and control processes can be manipulated for personal benefits through the issuance of tenders, permits, misappropriation of funds and many others. Prior study on the Malaysian public sector had shown that due to some areas of the public sector having least practices in fraud control, the level of fraud corruption remains high (Khalid \& Said, 2016)

\section{Fraud Prevention}

Over the years, there have been quite a number of methods to prevent and detect fraud in organisations. The common method of fraud detection is through common audits, where auditors are able to detect irregularities along with financial statements or financial reports (Gullkvist \& Jokipii, 2013). Red flags in financial statements can be found through manipulations of revenue, misrepresentation of expenses or usage of cookie jar accounting in order to manipulate growth and stability (Erickson, Hanlon, \& Maydew, 2004; Ruankaew, 2013). Although detection is usually enforced after a fraud has occurred, it is always prudent to prevent fraud from occurring again in the same organisation. This can be done with thorough implementations of a good internal control system which can prevent fraud from occurring in the future.

Despite the positive outlook, there are views mentioning that internal control is not an effective tool for organisations, as they have a late reaction and requires time to proceed and adapt with changes (Jensen, 1993). Internal control is indeed not a proactive tool that can be changed upon detection of mishaps. The lack of effectiveness of internal control is due to the cost of control towards fraud prevention being perceived to exceed the benefits (Dorminey, Scott Fleming, Kranacher, \& Riley, 2012). This budget constraint makes organisations select and chooses controls that can provide the best benefits for them. The more control that an organisation has, the less will be deviant incidence occurring within the organisation (Hollinger \& Clark, 1983).

The use of internal control as a deterrent to actions of fraud is related to opportunities that perpetrators might have. Research concerning internal control had always investigated on effects and weaknesses of internal control towards opportunities for fraud to occur in an organisation (Evans, 1978; Lokanan, 2015; Norby \& Stringer, 1978; Power, 2013; Weili \& Sarah, 2005). From previous literature, there were arguments that although internal control is strong, fraud will always occur as perpetrator will try to find other opportunities to commit fraud (Jack et al., 2010; Lokanan, 2015). There will be situations whereby internal control is not possible to be enforced, as there are coorperations between people committing the act of fraud (Ashforth \& Anand, 2003; Free et al., 2007). The case of Enron had shown that even the auditor can collude with insiders of an organisation, becoming are the perpetrators who fraudulently reported their financial statements, triggering to the collapse of investor confidence towards the company.

It was also argued that when one of the five components of internal control is not present or not functioning, there will be a deficiency to the entire system (COSO, 2013). The term deficiency comes about when there are shortcomings in some components of internal control that can adversely affect an organisation to obtain their objectives. When one of the components is incomplete, the organisation will not be able to process an effective internal control. Some of the areas that might not be present in the internal control mechanism include situations such as negative decisions of the organisation, whereby the results might lead to the failure of intended objectives. Studies on the effect of internal control deficiencies commonly associate internal control problems with their equity. The more equity that an organisation has, the higher will be its level of internal control, subsequently lowering the level of its deficiency (Petrovits, Shakespeare, 
\& Shih, 2011). The study of Petrovits, Shakespeare and Shih were more focused towards non-profit organisations, which showed that internal control is correlated with organisations size and growth, in addition to the equity that they have.

The overall framework had stated certain situations or control activities that may lead to the failure of internal control. These factors include items such as judgement, breakdown, management override and collusion. Some of these factors can lead to the failure of organisational objectives (COSO, 2012). Judgement factors occur when there are human elements involved in decision making towards the organisation. This is where an individual makes decisions based on the information he has or while being under pressure by the organisation. The results of such a decision may vary, as they can prove to be beneficial or lead to a non-desirable result. The breakdown factor occurs when there is a miscommunication on decisions or judgements made in the organisation. This miscommunication may arise in the form of misunderstood instructions or carelessness of the persons involved. Management override occurs when the ruling management decides to change or alter policies or procedures to suit their own interest (Tipgos, 2002). These can be in the form of changing processes or issuing orders that will have significant effects on organisational objectives. Management override can be for purposes of personal gain or even to obtain or show better results that will benefit certain individuals. The last factor that was discussed is collusion, which is a paramount element in failures of internal control. This can be due to control failures. When people or groups of people collude to conceal their actions from detections, the internal control system may not be able to detect the altercation. When there is collusion, it will be difficult for the internal control system to detect any omission of the process that has occurred. That is why organisations are very concerned if there are collusions and cooperation between employees as a factor of controlling fraud in their internal control systems that would result in loss of assets.

The United States, via its Government Accountability Office (GAO), had issued the Standards for Internal Control in the Federal Government, or more publicly known as the Green Book (Government Accountability Office, 2014). This sets the standards for effective internal control in federal agencies. The standards basically use these approaches towards internal control, identifying objectives, designing controls, making sure that controls are appropriately in place, and finally achieving objectives. The Green Book had utilised COSO Framework components in their standards of internal control, using the given components and underlying principals in each of these standards.

\section{DISCUSSION AND RECOMMENDATION}

The issue of addressing the matters of corruption is through two viewpoints. These viewpoints are in terms of engaging the matter in the public sector and the private sector. The public sectors have different values and objectives as compared to the private sector. Their motivations to work and rewards are different as compared to the private sector. The public sector may have more job security and pension funds. While the private sector has more monetary rewards which may be higher than normal values that can be through bonuses and incentives. This approach and clear differentiation in values in order to provide an effective recommendation to address the issues of corruption.

It is recommended to observe countries that have high levels of CPI index. These countries are successful in deterring the actions of corruption. The public sector in high CPI index countries such as New Zealand appoints ombudsman that is responsible for the appointments of public sector employees (Quah, 2017). The policies of these countries such as Singapore, Hong Kong and New Zealand have strong policies that improve their effectiveness in combatting corruption. The punishments in the public sector should be strict in order to prevent people from conduction corruptive behaviours. Heavy capital punishment to people that carry out acts of corruption helps remind society and enable them to learn that such behaviour has great risks (OECD, 2017).

The private sector observation shows that employees are the main actors of corruptive behaviours. Through having the right type rewards for the employees would help enable deter these acts of corruption (Mohamed, 2013). This past study had indicated that rewarding honest behaviours help deter such acts of corruption. The workers are also rewards handsomely when they perform well above their targeted performance.

The leaders in private organisations should not be left out in the overall improvement process. The literature discussion earlier had shown that leadership as the most catalyst for acts of corruption. Proper ethical training or education is important in order for them to set a good example to their employees. Prior studies had shown that ethical leaders influence organisational behaviour to good or bad (Paine, 1994). Managers or leaders who had failed to show a good example are more prone to unethical behaviours.

Table 4: Summary of recommendations

\begin{tabular}{cll}
\hline Sector & \multicolumn{1}{c}{ Method } & \multicolumn{1}{c}{ Recommendations } \\
\hline \hline \multirow{2}{*}{ Public } & Policy & Emulating successful countries that have effective anti-corruption strategies \\
& Motivations & Heavier capital punishment for acts of corruption \\
Private & Rewards that prevent acts of corruption \\
& Training & Train leaders to be more ethical \\
\hline
\end{tabular}




\section{CONCLUSION}

The overall development of fraud illustrated that it may occur in many types of form and factors. It is also very diverse on whether the actions are done individually or as a whole organisation. Individual factors are mostly explained by the fraud triangle theory, where personal motivations are often their common factors in committing these actions of fraud (Davis \& Pesch, 2013; Free, 2015; Free et al., 2007; Spira \& Page, 2003; Van Akkeren \& Buckby, 2015). Highlighted international cases showcased leadership as a common factor that leads toward these actions of fraud (Engelbrecht, Heine, \& Mahembe, 2017).

Theoretical models of fraud theories showed a number of different approaches in terms of fraud theories. It is not limited to only fraud triangle which was developed by Donald Cressey (Cressey, 1953, 1973), further, development had also included other dimensions, such as capabilities (Wolfe \& Hermanson, 2004), also competence and arrogance (Horwarth, 2014). This showed that these dimensions are open for discussion and are always dynamic in terms of approaches.

All in all, further development towards fraud factor, especially in terms of other approaches can be proposed in order to have a better understanding of fraud behaviour. Through a greater understanding of fraud, methods of prevention can also be further developed to improve organisation efficiency.

\section{REFERENCES}

Caccese, J. B., Buckley, T. A., Tierney, R. T., Arbogast, K. B., Rose, W. C., Glutting, J. J., \& Kaminski, T. W. (2018). Head and neck size and neck strength predict linear and rotational acceleration during purposeful soccer heading. Sports Biomechanics, 17(4), 462-476. https://doi.org/10.10ACFE. (2016). Report to The Nation on Occupation Fraud and Abuse. United States.

ACFE. (2017). Definition - Fraud Triangle.

Adawiah, E. R. (1998). Securities Regulation and the Prevention of Securities Fraud: A Comparative Study.

AICPA. (2006). AU Section 150. AICPA, (1), 525-537.

Ashforth, B. E., \& Anand, V. (2003). The Normalization of Corruption in Organizations. Research in Organizational Behavior, 25(03), 1-52. https://doi.org/10.1016/S0191-3085(03)25001-2

Bandler, J., \& Zimmerman, A. (2005). A Wal-Mart Legend's Trail of Deceit. Retrieved from https://www.wsj.com/articles/SB111291400324201359

BERNAMA. (2015). Pengerusi Eksekutif NFC bebas tuduhan pecah amanah. BERNAMA News. Retrieved from http://www.bernama.com/bernama/v8/bm/ge/newsgeneral.php?id=1193060

BERNAMA. (2016a). 37 Pegawai Imigresen dikenakan Tindakan Tatatertib. Sinar-Harian, p. 1. Retrieved from http://www.sinarharian.com.my/semasa/37-pegawai-imigresen-dikenakan-tindakan-tatatertib-1.527113

BERNAMA. (2016b). Bekas Penolong Pengarah Didakwa Rasuah, Lulus Pesanan Kerajaan RM45,572. Mstar.Com.My. Retrieved from http://www.mstar.com.my/berita/berita-mahkamah/2016/08/15/penolong-pengarah-rasuah/

Button, M. (2016). Fraud costing UK economy £193bn a year. Retrieved from http://uopnews.port.ac.uk/2016/05/25/fraud-costing-ukeconomy-193bn-a-year/

Button, M., \& Brooks, G. (2009). "Mind the gap", progress towards developing anti-fraud culture strategies in UK central government bodies. Journal of Financial Crime, 16(3), 229-244. https://doi.org/10.1108/13590790910971784

Chan, J. (2016). MACC arrests of Sabah officers give way to biggest seizure haul in history. Malay Mail Online, p. 1. Retrieved from http://www.themalaymailonline.com/malaysia/article/macc-arrests-of-sabah-officers-give-way-to-biggest-seizure-haul-inhistory\#sthash.1Gy591mR.dpuf

CIMA. (2008). Fraud Risk Management: A Guide to Good Practice. Chartered Institute of Management Accountants, CIMA's Newsletter.

COSO. (2012). Internal Control: Intergrated Framework. http://www.felaban.net/archivos_boletines_clain/archivo20140723210329PM.pdf

COSO. (2013). Internal Control: Integrated Framework (Executive Summary). Retrieved from http://coso.org/ICIntegratedFramework-summary.htm

Cressey, D. R. (1953). Other People's Money: A study of the social psychology of embezzlement. Free Press. Retrieved from http://psycnet.apa.org/psycinfo/1954-06293-000

Cressey, D. R. (1973). Other People's Money: A study of the social psychology of embezzlement. Montclair, N.J. and Patterson Smith. Retrieved from http://www.worldcat.org/title/other-peoples-money-a-study-in-the-social-psychology-ofembezzlement/oclc/628437

Davis, J. S., \& Pesch, H. L. (2013). Fraud dynamics and controls in organizations. Accounting, Organizations and Society, 38(6-7), 469-483. https://doi.org/10.1016/j.aos.2012.07.005

Dorminey, J., Scott Fleming, A., Kranacher, M. J., \& Riley, R. A. (2012). The Evolution of Fraud Theory. Issues in Accounting Education, 27(2), 555-579. https://doi.org/10.2308/iace-50131

Dugan, K. B. and I. J. (2002). Arthur Andersen's Fall From Grace Is a Sad Tale of Greed and Miscues. Wall Street Journal. Retrieved from https://www.wsj.com/articles/SB1023409436545200

Edelman, D., \& Nicholson, A. (2005). Arthur Anderson Auditors and Enron : What happened to their Texas CPA licenses? Journal of Finance and Accounting, 1-9.

Engelbrecht, A. S., Heine, G., \& Mahembe, B. (2017). Integrity, Ethical Leadership, Trust and Work Engagement. Leadership \& Organization Development Journal, 38(3), 368-379. https://doi.org/10.1108/LODJ-11-2015-0237

Erickson, M., Hanlon, M., \& Maydew, E. L. (2004). How Much Will Firms Pay for Earnings. The Accounting Review, 79(2), 387408.

Evans, J. R. (1978). Improving The Accounting Profession: A Shared Responsibility. Retrieved from http://www.sec.gov/Archives/edgar/data/1521036/000119312514247341/d715471ds1.htm

Firdaous Fadzil. (2016). DBKL executive director faces 18 charges involving RM4.4m Read more: The Star Online. Retrieved from http://www.thestar.com.my/news/nation/2016/09/09/kl-city-hall-executive-director-faces-18-corruption-charges/ 
Frank, J. M. and R. (2002). Adelphia Officials Are Arrested, Charged With "Massive" Fraud. Wall Street Journal. Retrieved from https://www.wsj.com/articles/SB1027516262583067680

Free, C. (2015). Looking Through the Fraud Triangle: A review and call for new directions. Meditari Accountancy Research, 23(2), 175-196. https://doi.org/10.1108/MEDAR-02-2015-0009

Free, C., \& Macintosh, N. (2006). Management Control Practice and Culture at Enron: The Untold Story. SSRN Electronic Journal, (August 2006), 1-35.

Free, C., Macintosh, N., \& Stein, M. (2007). Management Controls: The Organizational Fraud Triangle of Leadership, Culture and Control in Enron. Ivey Business Journal, 71(August), 1-10. https://doi.org/Article

GAO - Government Accountability Office. (2014). Standards for Internal Control in the Federal Government - GAO 14-704G (The Green Book), (September), 86.

Gee, J., Button, M., \& Brooks, G. (2011). The financial cost of healthcare fraud: What data from around the world shows, 1-24.

Gullkvist, B., \& Jokipii, A. (2013). Perceived Importance of Red Flags across Fraud Types. Critical Perspectives on Accounting, 24(1), 44-61. https://doi.org/10.1016/j.cpa.2012.01.004

Gunaratnam, S. (2016, April 21). Ex-Youth and Sports Ministry secretary, 3 directors charged with money laundering. New Straits Times Online. Retrieved from http://www.nst.com.my/news/2016/04/140654/ex-youth-and-sports-ministry-secretary-3directors-charged-money-laundering

Ho, S. S. M., Li, A. Y., Tam, K., \& Zhang, F. (2014). CEO Gender, Ethical Leadership, and Accounting Conservatism. Journal of Business Ethics, 1-20. https://doi.org/10.1007/s10551-013-2044-0

Hollinger, R. C., \& Clark, J. P. (1983). Theft by Employees. Lexington, MA: D.C. Heath.

Horwarth, C. (2014). Article on Fraud. Retrieved from http://crowehorwath.com.eg/uploadedfiles/my/insights/insights-assets/article on fraud.pdf

INTOSAI. (2016). Guidelines for Internal Control Standards for the Public Sector. Retrieved from http://www.issai.org/media/13329/intosai_gov_9100_e.pdf

Jack, D., Arron Scott, F., \& Mary-Jo, R. (2010). Beyond The Fraud Triangle. THE CPA Journal2, 80(7), 17-23.

Jamaludin, S. N. (2018). Rasuah RM4 juta, Pengarah JPS Perlis, 2 Kontraktor direman. Utusan Malaysia, p. 1. Retrieved from http://www.utusan.com.my/berita/mahkamah/rasuah-rm4-juta-pengarah-jps-perlis-2-kontraktor-direman-1.600012

Jensen, M. C. (1993). The Modern Industrial Revolution, Exit , and the Failure of Internal Control Systems the Failure of Internal Control Systems. Journal of Finance, 48(3), 831-880. https://doi.org/10.1111/j.1540-6261.1993.tb04022.x

Junior, R. O., \& Sorking, A. R. (2001). Enron's Collapse: The Overview. NYTIMES. Retrieved from http://www.nytimes.com/2001/12/03/business/enron-s-collapse-the-overview-enron-corp-files-largest-us-claim-forbankruptcy.html

Khalid, M. A., \& Said, J. (2016). Empirical Assessment of Good Governance in the Public Sector Of Malaysia. Interdisciplinary Approach to Economics and Sociology, 9(4), 289-304. https://doi.org/10.14254/2071-789X.2016/9-4/18

KPMG. (2013). Malaysia Fraud, Bribery and Corruption Survey, 1-72. https://doi.org/10.1007/s13398-014-0173-7.2

Lokanan, M. (2015). Challenges to the Fraud Triangle: Questions on its usefulness. In Accounting Forum (Vol. 39, pp. 201-224).

Lunenburg, F. C. (2012). Power and Leadership: An Influence Process. International Journal of Management, Business, and Administration, 15(1), 1-9.

Lupica, C. (2014). HealthSouth, Inc.: A Case of Corporate Fraud. Retrieved March 6, 2017, from https://stakeholder11.wordpress.com/2014/11/24/healthsouth-inc-a-case-of-corporate-fraud/

MACC. (2016). Corruption Index. Retrieved November 28, 2016, from http://www.sprm.gov.my/index.php/en/offenders-corruptionstatistic

MACC. (2017a). Bekas Ceo THHE Disiasat Sprm, Didakwa Pecah Amanah RM2.5 Juta. Retrieved from https://docs.google.com/gview?embedded=true\&url=http://www.sprm.gov.my/images/BekasCEO_THHEdisiasatSPRM_dida kwapecahamanah.pdf

MACC. (2017b). Pasangan Suami Isteri Pegawai Tldm Disiasat Sprm, Dihukum Penjara. Retrieved from https://docs.google.com/gview?embedded=true\&url=http://www.sprm.gov.my/images/PASANGANSUAMI_ISTERIPEGAW AITLDMDISIASATSPRMDIHUKMPENJARA.pdf

MACC. (2017c). Pengarah Syarikat Bergelar Dato' Dan Pegawai Glc Disiasat Sprm Didakwa Buat Tuntutan Palsu RM789,360.

MACC. (2017d). Penolong Pegawai Pejabat Tanah Dituduh Terima Suapan RM150,000. Retrieved from http://www.sprm.gov.my/images/Kenyataan_Media/PEGAWAIPEJABAT_TANAHDAERAHJBDITUDUHTERIMASUAP AN.pdf

Milwaukee, T. R. (2010). 'Robin Hood' banker gets 63 months for fraud in Illinois. Retrieved from http://bankembezzlement.blogspot.my/2010/12/robin-hood-banker-gets-63-months-for.html

Miwil, O. (2018). Bank Accounts Frozen, Properties Seized in JKNS Corruption Probe. New Straits Times Online, p. 1. Retrieved from https://www.nst.com.my/news/crime-courts/2018/01/328555/bank-accounts-frozen-properties-seized-jkns-corruptionprobe

Mohamed, M. (2013). Countering Fraud in the Insurance Industry : A Case Study of Malaysia Mudzamir Mohamed.

Nazlina, M. (2015). Khir Toyo's conviction upheld by Federal Court Read more at. Thestar.Com.My. Retrieved from http://www.thestar.com.my/news/nation/2015/09/22/court-khir-coviction/\#Zi2rr06jf0vmdqBV.99

Nick McKenzie, Richard Baker, J. G. (2015). Corrupt overseas buyers ramp up property price, burn locals. The Age. Retrieved from http://www.theage.com.au/national/corrupt-overseas-buyers-ramp-up-property-price-burn-locals-20150622-ghu5pn.html

Norby, W. C., \& Stringer, K. W. (1978). The Commission on Auditors' Responsibilities. Commission on Auditors' Responsibilities.

OECD. (2017). Fighting corruption, boosting integrity. Retrieved March 23, 2017, from http://www.oecd.org/general/fightingcorruptionboostingintegrity.htm

Olagbemi, F. O. (2010). The Effectiveness of federal regulations and corporate reputation in mitigating corporate accounting fraud. Argosy University.

Owens, K. \&. (2015). Preventing and Detecting Fraud at Not-for-Profit Organizations. Keller and Owens LLC, (December), 79-83.

Paine, L. S. (1994). Managing for Organizational Integrity. Harvard Business Review, 72(2), 106-117. Retrieved from http://ezproxy.library.capella.edu/login?url=http://search.ebscohost.com/login.aspx?direct=true\&db=bth\&AN=9405100924\&s ite=ehost-live \&scope $=$ site 
Petrovits, C., Shakespeare, C., \& Shih, A. (2011). The causes and consequences of internal control problems in nonprofit organizations. Accounting Review, 86(1), 325-357. https://doi.org/10.2308/accr.00000012

Petrucelli, J. R., \& Peters, J. R. (2016). Preventing Fraud and Mismanagement in Government: Systems and structures. John Wiley and Sons.

Power, M. (2013). The apparatus of fraud risk. Accounting, Organizations and Society, 38(6-7), 525-543. https://doi.org/10.1016/j.aos.2012.07.004

Price Waterhouse Coopers. (2014). What you don't know can hurt you. PwC's 2014 Global Economic Crime Survey - a threat to Malaysian business. PricewaterhouseCoopers.

Price Waterhouse Coopers. (2016). Global Economic Crime Survey 2016. PWC.

Quah, J. S. T. (2017). Singapore's Success in Combating Corruption: Lessons for policy makers. Asian Education and Development Studies, 6(3), 263-274. https://doi.org/10.1108/AEDS-03-2017-0030

Rashid, M. Z. A., Sambasivan, M., \& Rahman, A. A. (2004). The Influence of Organizational Culture on Attitudes toward Organizational Change. Leadership \& Organization Development Journal, 25(2), 161-179. https://doi.org/10.1108/01437730410521831

Rodrigues, J. (2015). Barings collapse at 20: How rogue trader Nick Leeson broke the bank. The Guardian, p. 1. Retrieved from https://www.theguardian.com/business/from-the-archive-blog/2015/feb/24/nick-leeson-barings-bank-1995-20-archive

Ruankaew, T. (2013). The Fraud Factors. International Journal of Management and Administrative Sciences (IJMAS), $2(2), 1-5$.

Ruankaew, T. (2016). Beyond the Fraud Diamond. International Journal of Business Management \& Economic Research, 7(1), 474476.

Sinar Harian. (2017). Rasuah: Dua penjawat awam pula direman. Sinar-Harian. Retrieved from http://www.sinarharian.com.my/semasa/rasuah-dua-penjawat-awam-pula-direman-1.625512

Sorking, A. R. (2002). 2 Top Tyco Executives Charged With $\$ 600$ Million Fraud Scheme. NYTIMES. Retrieved from http://www.nytimes.com/2002/09/13/business/2-top-tyco-executives-charged-with-600-million-fraud-scheme.html

Spira, L. F., \& Page, M. (2003). Risk management: The reinvention of internal control and the changing role of internal audit [Electronic Version]. Accounting, Auditing \& Accountability Journal, 16(4), 640-661. https://doi.org/10.1108/09513570310492335

Taub, S. (2006). Former Swissair CFO Faces Charges. CFO.Com.

The-Economist. (2003). The Dominican Republic Swindles. Retrieved March 6, 2017, from http://www.economist.com/node/1846189

TheBorneoPost. (2011). Auditor General's Report: Trim wastage and minimise corruption.

Tipgos, M. (2002). Why management fraud is unstoppable. The CPA Journal, 72(12), 34-41.

Van Akkeren, J., \& Buckby, S. (2015). Perceptions on the Causes of Individual and Fraudulent Co-offending: Views of Forensic Accountants. Journal of Business Ethics. https://doi.org/10.1007/s10551-015-2881-0

W. Steve, A., Ketich R., H., \& Marshall B., R. (1984). Deterring fraud : the internal auditor's perspective. Altamonte Springs, Fla. : Institute of Internal Auditors Research Foundation. Retrieved from http://trove.nla.gov.au/work/19067711?q\&versionId=22392868

Weili, G., \& Sarah, M. (2005). The diclosure of material weaknesses in internal control after the Sarbanes -Oxley Act. Accounting Horizons, 19(3), 137-158. https://doi.org/10.2308/acch.2005.19.3.137

Wilson, T., Verschoor, C. C., Tysiac, K., Tackett, J. A., Strischek, D., Smieliauskas, W., ... ACFE. (2014). Report To the Nations on Occupational Fraud and Abuse. Association of Certified Faud Examiners (Vol. 15). https://doi.org/http://dx.doi.org/10.2139/ssrn.2222608

Wolfe, D. T., \& Hermanson, D. R. (2004). The Fraud Diamond : Considering the Four Elements of Fraud. CPA Journal, 74(12), 38 42. https://doi.org/DOI:

World-Finance. (2011). The Parmalat Scandal. Retrieved March 6, 2017, from http://www.worldfinance.com/special-reports/theparmalat-scandal

80/14763141.2017.1360385

Huang, X., Sun, J., \& Sun, J. (2018). A car-following model considering asymmetric driving behavior based on long short-term memory neural networks. Transportation Research Part C: Emerging Technologies, 95(February), 346-362. https://doi.org/10.1016/j.trc.2018.07.022

James, S. L., Abate, D., Abate, K. H., Abay, S. M., Abbafati, C., Abbasi, N., Abbastabar, H., Abd-Allah, F., Abdela, J., Abdelalim, A., Abdollahpour, I., Abdulkader, R. S., Abebe, Z., Abera, S. F., Abil, O. Z., Abraha, H. N., Abu-Raddad, L. J., Abu-Rmeileh, N. M. E., Accrombessi, M. M. K., ... Murray, C. J. L. (2018). Global, regional, and national incidence, prevalence, and years lived with disability for 354 diseases and injuries for 195 countries and territories, 1990-2017: a systematic analysis for the Global Burden of Disease Study 2017. The Lancet, 392(10159), 1789-1858. https://doi.org/10.1016/S0140-6736(18)32279-7

Tan, H., Qin, L., Jiang, Z., Wu, Y., \& Ran, B. (2018). A hybrid deep learning based traffic flow prediction method and its understanding. Transportation Research Part C: Emerging Technologies, 90(January), 166-180. https://doi.org/10.1016/j.trc.2018.03.001

Taylor, K., Post, A., Hoshizaki, T. B., \& Gilchrist, M. D. (2019). The effect of a novel impact management strategy on maximum principal strain for reconstructions of American football concussive events. Proceedings of the Institution of Mechanical Engineers, Part P: Journal of Sports Engineering and Technology, 233(4), 503-513. https://doi.org/10.1177/1754337119857434 